\title{
PENDIDIKAN ASWAJA NU DALAM KONTEKS PLURALISME
}

\author{
Muhammad Fahmi \\ (Dosen STAI Taruna Surabaya)
}

\begin{abstract}
Abstrak
Tulisan ini berupaya memahami pendidikan aswaja NU dalam konteks pluralisme. Hasilnya menunjukkan bahwa pendidikan aswaja NU bersifat plural, multikultural, toleran, tasamuh, tawazun, dan sejenisnya. Lanaa a'maalana walakum a'malukum (bagi kami perbuatan kami, bagui kamu perbuatan kamu); lakum diinukum waliya diin (bagimu agamamu, bagiku agamaku). Jadi pendidikan NU itu berwawasan pluralistik. Pendidikan aswaja NU mengatur hubungan antar manusia dalam tiga macam ikatan di atas, yang menuju kepada persaudaraan/ kerukunan berdasar saling mengerti dan menghornati. Persaudaraan/kerukunan yang diajarkan oleh Islam ini disebut dengan persaudaraan (ukhuwah) yang diajarkan oleh Islam. Dengan mengemukakan tri ukhuwah di atas, Nahdlatul Ulama menegaskan bahwa Islam mengajarkan persaudaraan dengan segala macam kelompok manusia; antara lain kelompok seagama, sebangsa, dan sesama manusia di dunia.
\end{abstract}

Kata Kunci: Aswaja, NU, dan Pluralisme. 


\section{A. Pendahuluan}

Sebagai lembaga pendidikan yang tumbuh dan berkembang dari masyarakat sendiri, madrasah dan sekolah NU memiliki karakter yang khusus, yaitu karakter masyarakat; diakui sebagai milik masyarakat dan selalu bersatu dengan masyarakat, oleh masyarakat dan untuk masyarakat. Guru-guru madrasah adalah juga guru-guru masyarakat yang tingkah lakunya dinilai, diawasi, dan ditiru oleh masyarakat. Madrasah Ma'arif juga merupakan pusat kegiatan masyarakat pada beberapa bidang tertentu, khususnya pada bidang keagamaan. ${ }^{1}$

Dalam pendidikan NU, ada materi pembelajaran yang menjadi ciri khas atau corak khusus yang tidak boleh ditiadakan, yaitu materi Ahlus Sunna Wal Jama'ah (Aswaja). Materi aswaja yang dimaksud adalah aswaja an-nahdhiyah, sebab saat ini banyak aliran atau kelompok keagamaan yang mengklaim diri menjalankan aswaja, tetapi dalam praktiknya bertentangan dengan aswaja an-nahdhiyah. Jadi dalam tulisan ini yang dimaksud aswaja atau pendidikan aswaja adalah aswaja annahdhiyah, aswaja yang dikembangkan oleh organisasi terbesar di Indonesia, yaitu Nahdhatul Ulama.

\section{B. Aswaja sebagai Inti Pendidikan NU}

Dengan berpangkal pada doktrin Ahlun al-Sunnah wa al-Jama'ah (Aswaja) yang dianut dan dikembangkan, maka dalam berbagai gerak dan langkahnya, NU senantiasa memperlihatkan watak yang fleksibel dalam menerjemahkan dan menerima realitas. Dalam hal ini, selalu terbuka peluang bagi para pengikutnya untuk menginterpretasikan realitas yang bersifat given; dalam arti bahwa teks-teks agama yang dirujuk melegitimasi realitas tersebut sudah ada dan dilakukan oleh para ulama yang dalam tradisi NU berkedudukan sebagai mujtahid.

Jika selama ini masyarakat NU (bahkan para pengurusnya) memahami Aswaja secara fiqhiyah, dan mengikuti apa saja yang telah dihasilkan para ulama terdahulu, maka kini pengertian Aswaja difahami dalam kerangka manhaj al-fikr (metode berfikir). Dengan pemaknaan

\footnotetext{
${ }^{1}$ KH. Achmad Siddiq, Khittah Nahdliyyah, cet. III (Surabaya: Khalista-LTNU, 2005), 88 .
} 
Aswaja seperti itu, diharapkan memberikan kesempatan yang luas bagi umatnya untuk melakukan kreasi-kreasi orisinil dan inovatif sesuai dengan perkembangan zaman yang mereka hadapi. Pada titik ini, doktrin agama tetap dilihat sebagai pesan suci, dan berbekal akal fikiran, mereka melakukan eksperimentasi dalam tindakan sosial.

Pergeseran pemaknaan dan pemahaman Aswaja tersebut, secara de jure memang tidak diakui, dan dalam rumusan-rumusan formal (AD/ART) organisasi juga tidak memiliki dasar legitimasi, namun secara de facto, fenomena ini sudah menjadi umum sifatnya di kalangan komunitas NU, terutama di kalangan generasi muda NU Jawa Timur, yang embrionya dimulai sejak deklarasi Khittah NU 1926 di Situbondo tahun 1984, bersinggungan dengan tampilnya Abdurrahman Wahid sebagai Ketua Umum Tanfidziyah PBNU, dan mencapai puncak kristalisasi dan konsolidasi yang transparan pada dekade 1990-an.

Dalam hal transformasi keagamaan di lingkungan NU Said Aqil Siradj, ${ }^{2}$ salah satu pengurus PB NU, menyatakan:

"Pemahaman Aswaja sebagai metode berfikir (manhaj al-fikr) bukan madzhab harus menjadi titik awal kerangka berfikir dalam menggali hukum (syari'ah). Metode tersebut bersifat tawasuth, tawazun, tasamuh, dan selalu mencari jalan tengah (moderat) yang diterima oleh sebagaian besar golongan."

Dengan menggunakan doktrin Aswaja dalam kerangka manhaj al-fikr, yang dalam konteks sosial-kemasyarakatan berpangkal pada landasan pokok yakni tawasuth (moderat), tasamuh (toleran), tawazun (seimbang), al-'Adalah (keadilan), dan amar ma'ruf nahi munkar (mendorong perbuatan baik dan mencegah perbuatan munkar), maka hal ini telah memberikan justifikasi teologis kepada generasi NU untuk bersikap kritis dalam menafsirkan realitas, bersikap adil dan seimbang dalam menerima dan menempatkan perbedaan, dan menjaga jarak dengan kekuasaan dalam upaya tetap mempertahankan independensi dan sikap moderat.

Dalam praksisnya, metode tersebut telah memberikan warna baru di lingkungan masyarakat muda NU yang dalam dinamikanya cenderung

${ }^{2}$ Said Aqil Siradj, Ahlus Sunnah Wal-Jama'ah dalam Lintas Sejarah (Yogyakarta, LKPSM, 1998) 
liberal dan dalam aspek-aspek tertentu tidak mudah tunduk dengan postulat-postulat resmi agama. Fakta ini sekaligus telah menghancurkan tesis lama yang menilai bahwa doktrin Aswaja yang digunakan masyarakat NU hanya sekedar dijadikan alat untuk melegitimasi realitas, sehingga hampir tidak ada lagi sifat kritis ajaran atau doktrin terhadap realitas, karena daya kritis dan koreksi itu telah berakhir ketika teks-teks fiqih yang dirujuk itu tampil sebagai pemberi legitimasi realitas.

NU dan Aswaja memang ibarat dua sisi mata uang. Ketika menyebut NU, akan terbayang dalam fikiran kita para imam besar: imam al-Asy'ari dan al-Maturidi dalam bidang teologi; imam Hanafi, Maliki, Syafi' i, Hanbali dalam bidang fiqh; imam al-Junaid dan al-Ghazali dalam bidang tasawuf. NU telah mengembangkan faham Aswaja yang berpangkal dari pandangan-pandangan mereka. Oleh karena itu NU selalu menampakkan watak yang fleksibel dalam menyikapi realitas.

Akan tetapi, selama ini kebanyakan masyarakat NU terjebak pada pemahaman Aswaja secara fiqhiyah dan mengikuti apa saja yang telah dihasilkan oleh para ulama terdahulu (taklid). Menyadari realitas yang demikian itu, akhir-akhir ini terdapat fenomena adanya "pergeseran" pemaknaan dan pemahaman baru terhadap Aswaja yang mengarah pada paradigma manhaj al-fikr (metode berfikir). Dalam hal ini peran KH. Abdurrahman Wahid (Gus Dur) ketika memegang kendali NU selama tiga periode terlihat sangat signifikan dalam transformasi pemahaman keagamaan di kalangan masyarakat NU. ${ }^{3}$ Tak pelak, banyak generasi muda NU (jajaran struktural maupun kultural) terkena "virus pencerahan" tersebut, sehingga sikap kritisisme di kalangan generasi muda NU tumbuh subur.

NU menyadari bahwa keagamaan yang dianutnya -bukan tidak mungkin- akan tumpul dalam menghadapi perkembangan zaman. Oleh karena itu, NU menegaskan bahwa sumbangannya terhadap upaya pemecahan masalah-masalah dasar yang dihadapi umat kaitannya dengan pembangunan, bisa dan harus berbentuk upaya pengembangan doktrin

\footnotetext{
${ }^{3}$ Faisal Ismail, NU, Gusdurisme, dan Politik Kiai (Yogyakarta: Tiara Wacana, 1999) 
Ahlus Sunnah Waljama'ah (Aswaja) yang disesuaikan dengan tuntutan zaman. ${ }^{4}$

Demikianlah, bahwa landasan filosofis NU (termasuk ranah pendidikannya) adalah Ahlus Sunnah Waljama'ah (Aswaja). Aswaja bisa dimaknai secara klasik dan kontemporer. Dalam pengertian klasik, Aswaja berarti mengikuti jejak Imam al-Asy'ari dan al-Maturidi dalam bidang teologi; Imam Hanafi, Maliki, Syafi'i, Hanbali dalam bidang fiqh; imam al-Junaid dan al-Ghazali dalam bidang tasawuf. Sementara itu secara kontemporer, Aswaja bersifat dan bermakna fleksibel sesuai dengan tuntutan zaman dengan prinsip Tawazun, Tawasuth, Tasamuh, 'Adalah, dan Amar Ma'ruh Nahi Munkar.

\section{Pemaknaan Aswaja}

Bertolak dari telaah terma Nahdlatul Ulama (NU), secara etimologis, al-Nahdlah berarti kemampuan, kekuatan, loncatan, terobosan dalam upaya memajukan masyarakat atau yang lain. Sementara secara epistemologis berarti menerima segala budaya lama dari sisi kebudayaan yang lebih baru, dengan melakukan rekonstruksi dan reformasi ${ }^{5}$ atau secara lugas berarti kebangkitan atau gerakan yang dipelopori para ulama. Secara teknis berarti organisasi sosial keagamaan (Jam'iyah Diniyah) yang didirikan oleh para ulama tradisional dan usahawan Jawa Timur yang berfaham Ahlus Sunnah Waljama'ah pada tanggal 12 Rajab 1344/ 31 Januari 1926 M.

Ahlus Sunnah Waljama'ah (Aswaja) terdiri dari tiga suku kalimat; Ahlun, al-Sunnah, dan al-Jama'ah. Ahlun dapat berarti famili, kerabat, keluarga, penduduk, sebagaimana dalam ungkapan ahlul qaryah; dan dapat juga berarti pemeluk atau pengikut, sebagaimana dalam ungkapan ahlul madzhab. Al-Sunnah searti dengan attariqah yang berarti metode, jalan yang ditempuh, kebiasaan, perjanjian hidup atau perilaku baik atau tercela. Dalam hadits Nabi, riwayat Muslim, "baik" disebut

\footnotetext{
4 Lembaga Pendidikan Ma'arif Nahdlatul Ulama, Hasil Keputusan-Keputusan Musyawarah Kerja Nasional LPM-NU ke III: Sistem Pendidikan di Lingkungan Nahdlatul Ulama sebagai Sub Sistem Pendidikan Nasional; Lampiran 8 Landasan Dasar Kebijaksanaan Pendidikan di Lingkungan Nahdlatul Ulama (Jakarta, tt.), 3

${ }^{5}$ Said Agil Siradj, Ahlus Sunnah Wal-Jama'ah dalam Lintas Sejarah..., 14-15
} 
dengan ungkapan sunnatan hasanatan dan "tercela" disebut sunnatan sayyiatan. Menurut Ibnu Katsir, yang dikutip oleh Muhammad Abdulhadi al-Mishri, kata sunnah arti asalnya adalah perjalanan hidup Nabi. ${ }^{6}$

Di dalam al-Quran biasanya terma sunnah muncul dalam dua konteks; 1) Sunnah al-Awwalin, yang berarti kebiasaan orang-orang terdahulu, ${ }^{7}$ dan 2) Sunnah Allah (ketentuan Allah -pen.). ${ }^{8}$ Menurut istilah syara dan juga para ahli hadits, sunnah berarti segala sesuatu yang diriwayatkan dari Nabi Muhammad Saw., baik berupa perkataan, perbuatan, ketetapan, karakter, akhlaq atau perilaku; baik sebelum maupun sesudah diangkat menjadi Nabi/Rasul. Dalam hal ini pengertian sunnah searti degan hadits.

Menurut ahli ushul Fiqih, sunnah (dalam pengertian hadits) adalah segala sesuatu yang dinukil (diambil) dari Nabi Muhammad Saw. secara khusus. Assunnah tidak ada nashnya dalam al-Quran, tetapi dinyatakan oleh Nabi, sekaligus merupakan penjelasan awal atas alQuran dan dapat dijadikan landasan serta dalil hukum syara. Sementara menurut fuqaha, sunnah adalah perbuatan terpuji, bukan wajib, dan terkadang digunakan sebagai lawan dari kata karahiyah (yang dibenci).

Al-Jama'ah artinya sekumpulan. Semua orang Islam merupakan kesatuan (Jama'ah), tanpa memandang latar belakang; asal mereka orang Islam, harus dianggap jama'ah. Jama'ah juga berarti mayoritas penganut dan pembela sunnah Nabi. Di kalangan NU, Ahlus Sunnah Waljama'ah juga difahami sebagai pembeda dengan kelompok modernis yang menyatakan bahwa dalam beragama (Islam) orang hanya wajib berpegang teguh pada al-Quran dan al-Hadits. Masyarakat NU disamping berpegang teguh pada al-Quran dan al-Hadits- juga berpegang pada sunnah para sahabat dan Ijma' para ulama. ${ }^{9}$

Tidak bisa dipungkiri, bahwa gerak dinamika sosial NU, di satu sisi memang masih sering tersentral pada figur Gus Dur, namun di sisi lain keberadaan kaum mudanya merupakan segmen otoritas dan kekuatan

\footnotetext{
${ }^{6}$ Muhammad Abdulhadi al-Mishri, Manhaj Aqidah Ahlussunnah wal jama'ah menurut Pemahaman Ulama Salaf, terj. As'ad Yasin, Abu Fahmi Ibnu Maryam (Jakarta: Insan Press, 1992), 105

${ }^{7}$ Qs. Al-Anfal (8): 38; al-Hijr (15): 13; al-Kahfi (18): 55; Fathir (35): 43

${ }^{8}$ Qs. Al-Naml (27): 77; Fathir (35): 43

${ }^{9}$ PB NU, Khittah Nahdlatul Ulama (Jakarta: Lajnah Ta'lif an-Nasyr, 1985), 10 
yang tidak bisa diabaikan begitu saja. Signifikansi peran yang dimainkan oleh kelompok muda ini setidaknya mulai tampak pada satu dasawarsa terakhir, yang benih-benihnya mulai muncul pasca Muktamar Situbondo 1984, yang kemudian ditandai dengan lahirnya generasi baru di tubuh NU, yang jika dilihat dari mereka yang mendirikan NU, maka generasi ini mewakili generasi ketiga. ${ }^{10}$ Peran generasi ketiga NU inilah yang menyosialisasikan pergeseran pemahaman Aswaja dari generasi kedua NU ke kader-kader bawah NU.

\section{Hakikat Aswaja}

Dengan tidak memonopoli predikat sebagai satu-satunya golongan Ahlussunnah wal Jamaah, Jam'iyyah (Aswaja) NU semenjak berdirinya menegaskan diri sebagi penganut, pengemban dan pengembang Islam ala Aswaja. Dengan sekuat tenaga, NU berusaha menempatkan diri sebagai pengamal setia dan mengajak seluruh Kaum Muslimin, terutama para warganya untuk menggolongkan diri pada Aswaja.

Pada hakikatnya, Aswaja adalah ajaran Islam yang murni sebagaimana diajarkan dan diamalkan oleh Rasulullah SAW. dan para sahabatnya. Ketika Rasulullah SAW menerangkan bahwa umatnya akan terpecah dan tergolong menjadi banyak sekali (73) golongan, beliau menegaskn bahwa yang benr dan selamat dari sekian banyak golongan itu hanyalah Ahlussunnah wal Jamaah. Atas pertanyaan para sahabat, apakah As Sunnah wal Jamaah itu, beliau merumuskan dengan sabdanya "Maa ana 'alaihi al yaumi wa ashhabii" (Apa yang aku berada di atasnya, hari ini, bersama para sahabatku). ${ }^{11}$

Aswaja adalah golongan pengikut setia pada As-Sunnah wal Jamaah, yaitu ajaran Islam yang diajarkan dan diamalkan oleh Rasulullah SAW bersama para sahabatnya pada zamannya. Aswaja bukanlah sesuatu yang baru timbul sebagai reaksi dari timbulnya beberapa aliran yang menyimpang dari ajaran yang murni seperti Syi'ah, Khawarij, Mu'tazilah, dan sebagainya. Awaja sudah ada sebelum semuanya itu

${ }^{10}$ Laode Ida, Anatomi Konflik: NU Elit Islam dan Negara (Jakarta: Sinar Harapan, 1996)

${ }^{11}$ KH. Achmad Siddiq, Khittah Nahdliyyah, 27-28 
timbul. Aliran-aliran itulah yang merupakan gangguan terhadap kemurnian Aswaja. Setelah gangguan itu membadai dan berkecamuk, dirasakan perlunya predikat Aswaja, dipopulerkan oleh kaum Muslimin yang tetap setia menegakkan As Sunnah wal Jamaah, mempertahankannya dari segala macam gangguan yang ditimbulkan oleh aliran-aliran yang mengganggu itu. Mengajak seluruh pemeluk Islam untuk kembali kepada Aswaja. ${ }^{12}$

Kalau pengumpulan dan penyusunan catatan-catatan ayat-ayat Al-Quran menjadi suatu mushhaf itu selesai di zaman sahabat, maka penyusunan hadits baru dirintis dan dilakukan oleh para tabiin. Selnajutnya seleksi, kategorisasi, sistematisasinya dirumuskan oleh generasi-generasi sesudahnya. Segala macam syarat, sarana dan methoda untuk menyimpulkan pendapat yang benar dan murni dari Al-Quran dan al-Hadits diciptakan dan dikembangkan. Mulai dari ilmu bahasa Arab, nahwu, sharaf, ma'ani, badi' dan bayan sampai kepada ilmu mantiq (logika) dan filsafat, dirangkaikan dengan ilmu tafsir, ilmu musthalah hadits sampai kepada ushul fiqih dan al-Qawaidul fiqhiyyah. Semuanya dimaksudkan untuk dapat mencapai kemurnian ajaran Aswaja.

Mereka, Assabiqunal Awwalun (generasi terdahulu), bergerak ke segala penjuru dunia, dengan segala jerih payah, dengan penderitaan dan pengorbanan menyebarkan Aswaja kepada seluruh umat manusia (Kaaffatan linnaas). Termasuk di Indonesia, para muballighin, atas resiko sendiri tanpa dukungan kekuasaan politik dan kekuatan materiil yang berarti, membawa Aswaja. Dengan tidak mengurangi peranan para muballighin yang lain, para wali atau muballighin yang terkenal dengan istilah wali songo adalah kelompok yang paling berkesan dalam sejarah penyebaran Islam di Indonesia khususnya di tanah Jawa. ${ }^{13}$

Menurut Achmad Siddiq, ${ }^{14}$ sistem dan methoda untuk sampai pada ajaran Aswaja adalah dengan berijtihad bagi mereka yang telah memenuhi syarat secara keilmuan, dan taqlid bagi mereka yang tidak cukup memiliki keilmuan dalam berijtihad. Memaksa semua umat Islam untuk berijtihad bukan saja tidak tepat teapi hal ini sangat membahayakan

\footnotetext{
${ }^{12}$ KH. Achmad Siddiq, Khittah Nahdliyyah, 28-29

${ }^{13}$ KH. Achmad Siddiq, Khittah Nahdliyyah, 34-35.

${ }^{14}$ KH. Achmad Siddiq, Khittah Nahdliyyah, 37 
Aswaja. Sebagaimana sabda Rasulullah SAW. "Idzaa wusidal amru ilaa ghairi ahlihi faantadhiris saa'ah"15 (Ketika suatu perkara diserahkan kepada orang yang bukan ahlinya, maka tunggulah saat (kehancuran perkara itu).

Dalam tradisi NU, bertaqlid (mengikuti pendapat orang lain) itu dibatasi kepada pendapat yang sudah merupakan rangkaian yang lengkap (madzhab) dan pendapat-pendapat itu di-tadwin (tercatat dan terpelihara secara tertib); tidak boleh bermadzhab kepada setiap orang yang hanya mempunyai pendapat mengenai satu atau dua masalah secara terpotongpotong. Kata Taqlid berasal dari kata qallada yang berarti mengikat atau mengikut. Setelah itu dipakai dalam istilah agama dalam arti, mengikuti pendapat orang lain yang diyakini kebenarannya sesuai dengan Al-Quran dan al-Hadits. Bertaqlid, tidak selalu identik dengan mengikut secra membuta tuli yang dalam bahasa Arab diungkapkan dengan taqlid a'ma (taqlid buta), tanpa sama sekali mempertimbangkan apakah pendapat yang diikuti itu benar atau sesat. ${ }^{16}$

Memang, pada tingkat pertama semua orang pasti mengalami proses mengikuti tanpa mengerti kekuatan pendapat yang diikuti. Anak (atau orang dewasa pun) yang baru belajar shalat, pasti ia mengikuti pelajaran gurunya tanpa mempersoalkan dalil-dalilnya, kuat atau tidak. Akan tetapi setelah tingkat pertama (permulaan) terlampaui, maka harus diusahakan supaya pengetahuannya meningkat, menurut kemampuan dan kesempatan yang ada. Sewajarnya, ia harus mengetahui dan meyakini kebenaran pelajaran yang diikutinya, dengan berusaha mengetahui dalildalilnya. Dengan hanya sedikit mengetahui dalil-dalil itu, maka tidak berarti ia terlepas dari tingkatan bertaqlid.

Secara nyata, NU berusaha meningkatkan kemampuan para muqallidun (orang-orang yang bertaqlid) supaya tidak selalu berada pada tingkat yang pertama/ permulaan. Di pesantren dan madrasah, para ulama NU berusaha memberikan pelajarann ilmu agama dalam kadar yang memadai, tidak hanya untuk menjadi muqallid a'ma tetapi untuk memiliki kemampuan lebih tinggi lagi, untuk menjadi muqallid yang lebih baik. Dalam pada itu, betapapun banyak ilmu agama yang

${ }^{15}$ Al-Hadits al-Nabawy

${ }^{16}$ KH. Achmad Siddiq, Khittah Nahdliyyah, 54-55 
diajarkan, para ulama tetap tahu diri dan mendidik para santri dan muridnya untuk selalu tahu diri, bahwa dengan ilmu yang didapatnya itu tidak berarti sudah cukup untuk menjadi mujtahid sendiri. Juga mereka dididik untuk tidak merasa menjadi mujtahid, padahal sesunggguhnya tetap mengikuti pendapat orang lain yang disukainya saja, mungkin bukan Imam Maliki, atau Hanafi, atau Hanbali, tetapi Imam atau tokoh yang lain. ${ }^{17}$

\section{E. Pengamalan Aswaja}

Di dalam naskah Khittah NU 1926 dinyatakan, bahwa Khittah Nahdlatul Ulama adalah landasan berfikir, bersikap dan bertindak warga Nahdlatul Ulama yang harus dicerminkan dalam tingkah laku perorangan maupun organisasi serta dalam setiap proses pengambilan keputusan. Landasan tersebut adalah faham Islam Ahlussunnah Waljama'ah yang diterapkan menurut kondisi kemasyarakatan di Indonesia, meliputi dasardasar amal keagamaan maupun kemasyarakatan. Khittah Nahdlatul Ulama juga digali dari intisari perjalanan khidmahnya dari masa ke masa. ${ }^{18}$

Naskah Khittah NU butir 3 menyebutkan, 1. Nahdlatul Ulama mendasarkan faham keagamaannya kepada sumber ajaran Islam: Al Quran, As Sunnah, Al Ijma' dan Al Qiyas. 2. Dalam memahami, menafsirkan Islam dari sumber-sumbernya tersebut di atas, Nahdlatul Ulama mengikuti faham aswaja dan menggunakan jalan pendekatan al Madzhab: a. Di dalam bidang aqidah, Nahdlatul Ulama mengikuti faham ahlussunnah waljama'ah yang dipelopori oleh Imam Abul Hasan Al Asy'ari dan Imam Abu Manshur Al Maturidi, b. Di bidang fiqh, Nahdlatul Ulama mengikuti jalan pendekatan (al madzhab) salah satu dari madzhab Imam Abu Hanifah An Nu'man, Imam Malik bin Anas, Imam Muhammad bin Idris Asy Syafi'I dan Imam Ahmad bin Hambal, c. Di bidang tashawwuf mengikuti antara lain Imam Al Junaid Al Bghdadi dan Imam Al Ghazali, serta Imam-Imam yang lain. ${ }^{19}$

\footnotetext{
${ }^{17}$ KH. Achmad Siddiq, Khittah Nahdliyyah, 55-56.

18 Abdul Muchith Muzadi, Mengenal Nahdlatul Ulama, Cet. IV (Jember: Masjid Sunan Kalijaga, 2006), 19.

${ }^{19}$ Muchith Muzadi, Mengenal Nahdlatul Ulama, 28-29

Jurnal Pendidikan Agama Islam

Volume 01 Nomor 01 Mei 2013

Hal $170-179$
} 
3. Nahdlatul Ulama mengikuti pendirian, bahwa Islam adalah agama yang fithri yang bersifat menyempurnakan segala kebaikan yang sudah dimiliki oleh manusia. Faham keagamaan yang dianut Nahdlatul Ulama bersifat menyempurnakan nilai-nilai yang baik yang sudah ada dan menjadi milik serta ciri-ciri suatu kelompok manusia seperti suku maupun bangsa dan tidak bertujuan menghapus nilai-nilai tersebut.

Nahdlatul Ulama berpendirian bahwa faham aswaja harus diterapkan dalam tata kehidupan nyata di masyarakat dengan serangkaian sikap yang bertumpu pada karakter tawasuth, tasamuh, tawazun, 'adalah, dan amar ma'ruf nahi munkar. Penjabaran dari nilai-nilai tersebut adalah sebagai berikut.

Pertama, tawasuth (moderat); sikap tengah yang berintikan kepada prinsip hidup yang menjunjung tinggi keharusan berlaku adil dan lurus di tengah kehidupan bersama. Nahdlatul Ulama dengan sikap dasar ini akan selalu menjadi kelompok panutan yang bersikap dan bertindak lurus dan selalu bersifat membangun serta menghindari segala bentuk pendekatan yang bersifat tatharruf (ekstrim).

Tawasuth (pertengahan) diambil dari firman Allah SWT (dari kata wasathan);

"Dan demikianlah, Kami telah menjadikan kamu sekalian (umat Islam) umat pertengahan (adil dan pilihan) agar kamu menjadi saksi (ukuran penilaian) atas (sikap dan perbuatan) manusia dan supaya Rasulullah SAW menjadi saksi (ukuran penilaian) atas (sikap dan perbuatan) kamu sekalian..., 20

Rasulullah SAW. menjadi pengukur umat Islam; sedangkan umat Islam menjadi pengukur manusia pada umumnya. ${ }^{21}$

Kedua, tasamuh (toleran); sikap toleran terhadap perbedaan, baik dalam masalah keagamaan, terutama hal-hal yang bersifat furu' atau menjadi masalah khilafiyah, serta dalam masalah kemasyarakatan dan kebudayaan. Ketiga, tawazun (seimbang); sikap seimbang dalam berkhidmah, menyerasikan kepada Allah SWT, khidmah kepada sesama manusia serta kepada lingkungan hidupnya. Menyelaraskan kepentingan

20 QS. Al-Baqarah: 143.

${ }^{21}$ KH. Achmad Siddiq, Khittah Nahdliyyah, 60. 
masa lalu, masa kini dan masa mendatang. Tawazun juga berarti tidak berat sebelah, tidak berlebihan atau kekurangan suatu unsur; diambil dari kata al-Waznu atau al-Mizan (alat penyeimbang), dari ayat;

"Sungguh, Kami telah mengutus Rasul-rasul Kami dengan membawa bukti kebenaran yang nyata dan telah Kami turunkan bersama mereka al-Kitab dan Neraca (penimbang keadilan) supaya manusia dapat melaksanakan keadilan (al-Qisth)...,"22

Keempat, al-I'tidal/'adalah (tegak lurus/adil); tidak condong ke kanan dan tidak condong ke kiri, diambil dari kata al-'adlu (keadilan) atau i'diluu (bersikap adillah) pada ayat;

"Hai orang-orang yang beriman! Hendaklah kamu sekalian menjadi orang yang tegak (membela kebenaran) karena Allah SWT menjadi saksi (pengukur kebenaran) yang adil (bil qisthi). Dan janganlah sekali-kali kebencianmu kepada kaum, mendorong kamu untuk berlaku tidak adil. Berlaku adillah! Keadilan itu lebih dekat kepada taqwa. Dan bertaqwalah kepada Allah dan Allah itu Maha Melihat terhadap apa yang kamu kerjakan. ${ }^{23}$

Kelima, amar ma'ruf nahi munkar; selalu memiliki kepekaan untuk mendorong perbuatan baik, berguna dan bermanfaat bagi kehidupan bersama, serta menolak dan mencegah semua hal yang dapat menjerumuskan dan merendahkan nilai-nilai kehidupan. Sikap tawasuth ini sangat penting bagi Nahdlatul Ulama. Sikap ini bersumber dari ajaran Islam dan sesuai dengan karakter bangsa Indonesia umumnya. ${ }^{24}$

Menurut KH. Achmad Siddiq, ${ }^{25}$ penerapan sikap Tawasuth (dengan berbagai dimensinya) bukan berarti bersifat serba boleh (kompromistis) dengan mencampuraduk semua unsur (sinkretisme). Juga bukan mengucilkan diri dan menolak pertemuan dengan unsur lain. Karakter At Tawasuth dalam Islam adalah titik tengah di antara dua ujung (At Tatharruf = ekstrimisme), dan hal itu merupakan kebaikan yang sejak semula telah diletakkan Allah SWT. Prinsip dan karakter Tawasuth yang

\footnotetext{
${ }^{22}$ QS. Al-Hadid: 25.

${ }^{23}$ QS. Al-Maidah: 9.

${ }^{24}$ Muchith Muzadi, Mengenal Nahdlatul Ulama, 29-30.

${ }^{25}$ KH. Achmad Siddiq, Khittah Nahdliyyah, 62-63.
} 
sudah menjadi karakter Islam ini harus diterapkan dalam segala bidang, supaya agama Islam dan sikap serta tingkah laku umat Islam selalu menjadi saksi dan pengukur kebenaran bagi semua sikap dan tingkah laku manusia pada umumnya.

Manifestasi prinsip dan karakter At Tawasuth ini tampak pada segala bidang ajaran agama Islam, dan harus dipertahankan, dipelihara dan dikembangkan sebaik-baiknya, terutama oleh kaum Aswaja (pengikut setia Assunnah wal Jamaah). Penerapan at tawasuth dalam bidang agama Islam dapat dikemukakan seperti di bawah ini.

1. Pada bidang aqidah:

a. Keseimbangan antara penggunaan dalil aqli (argumentasional) dengan dalil naqli (nash al-Quran dan al-Hadits) dengan pengertian, bahwa dalil aqli dipergunakan dan ditempatkan di bawah dalil naqli.

b. Berusaha sekuat tenaga memurnikan aqidah dari segala campuran aqidah dari luar Islam.

c. Tidak tergesa-gesa dalam menjatuhkan vonis musyrik, kufur dan sebagainya atas mereka yang karena satu dan lain hal belum dapat memurnikan Tauhid atau aqidahnya secara murni.

2. Pada Bidang Syari'ah:

a. Selalu berpegang teguh pada Al-Quran dan As Sunnah, dengan menggunakan methoda dan sistem yang dapat dipertanggungjawabkan dan melalui jalur-jalur yang wajar.

b. Pada masalah yang sudah ada dalil nash yang sharih dan qath'I (tegas dan pasti), tidak boleh ada campur tangan pendapat akal.

c. Pada masalah yang dhanniyat (tidak tegas dan tidak pasti), dapat ditoleransi adanya perbedaan pendapat selama masih tidak bertentangan dengan prinsip agama. ${ }^{26}$

3. Pada Bidang Tasawuf atau Akhlaq:

a. Tidak mencegah, bahkan menganjurkan usaha memperdalam penghayatan ajaran Islam, dengan riyadlah dan mujadalah menurut kaifiyah yang tidak bertentangan dengan prinsip-prinsip hukum dan ajaran Islam.

${ }^{26}$ KH. Achmad Siddiq, Khittah Nahdliyyah, 63-64. 
b. Mencegah ekstrimisme dan sikap berlebihan (al-Ghuluwwu) yang dapat menjerumuskan orang kepada penyelewengan aqidah dan syari'ah.

c. Berpedoman bahwa akhlaq yang luhur selalu berada di antara dua ujung (tatharruf); misalnya Syaja'ah (berani) adalah sikap di antara jubn (penakut) dan sembrono (at tahawwur), tawadlu' (rendah hati) adalah sikap di antara takabbur (sombong) dan tadzallul (rendah diri), jud atau karom (loman, dermawan) adalah sikap di antara bukhl (kikir) dan israf (boros).

4. Pada bidang Mu'asyarah (pergaulan) antar golongan:

a. Mengakui watak tabiat manusia yang selalu senang berkelompok dan bergolongan berdasarkan atas unsur pengikatnya masing-masing.

b. Pergaulan antar golongan harus diusahakan berdasar saling mengerti dan saling menghormati.

c. Permusuhan terhadap suatu golongan, hanya boleh dilakukan terhadap golongan yang nyata memusuhi agama Islam dan umat Islam, tidak boleh ada sikap lain kecuali sikap tegas.

5. Pada Bidang Kehidupan Bernegara:

a. Negara nasional (yang didirikan bersama oleh seluruh rakyat) wajib dipelihara dan dipertahankan eksistensinya.

b. Penguasa negara (pemerintah) yang sah harus ditempatkan pada kedudukan yang terhormat dan ditatati, selama tidak menyeleweng dan/atau memerintah ke arah yang bertentangann dengan hukum Allah.

c. Jika terjadi kesalahan dari pihak pemerintah, cara memperingatkannya melalui tatacara yang sebaik-baiknya. ${ }^{27}$

6. Pada bidang Kebudayaann:

a. Kebudayaan, termasuk di dalamnya adat istiadat, tata pakaian, kesenian dan sebagainya adalah hasil budidaya manusia yang harus ditempatkan pada kedudukan yang wajar dan bagi pemeluk agama, kebudayaan harus dinilai dan diukur dengan norma-norma hukum dan ajaran agama.

b. Kebudayaan yang baik, dalam arti menurut norma agama, dari mana pun datangnya dapat diterima dan dikembangkan. Sebaliknya, yang

${ }^{27}$ KH. Achmad Siddiq, Khittah Nahdliyyah, 64-66 
tidak baik harus ditinggalkan; yang lama yang baik dipelihara dan dikembangkan, yang baru yang lebih baik dicari dan dimanfaatkan (Almukhafadlatu 'alal qadiimis shalih wal akhdzu bil jadiidil ashlakh).

c. Tidak boleh ada sikap apriori, selalu menerima yang lama dan menolak yang baru atau sebaliknya selalu menerima yang baru dan menolak yang lama.

7. Pada Bidang Dakwah:

a. Berdakwah adalah mengajak masyarakat untuk berbuat menciptakan keadaan yang lebih baik, terutama menurut ukuran ajaran Agama. Tidak mungkin orang berhasil mengajak seseorang dengan cara yang tidak mengenakkan hati yang diajak. Berdakwah bukan menghukum.

b. Berdakwah harus dilakukan dengan sasarann tujuan yang jelas, tidak hanya sekedar mengajak berbuat saja menurut selera.

c. Berdakwah harus dilaksanakan dengan keterangan yang jelas, dengan petunjuk-petunjuk yang baik, sebagaimana seorang dokter atau perawat yang berbuat baik kepada pasien. Kalau terdapat kesulitan itu harus ditanggulangi dan diatasi dengan cara yang sebaik-baiknya. ${ }^{28}$

\section{F. Pendidikan Aswaja NU dalam Konteks Pluralisme}

Sejak semula, sesuai dengan ajaran Islam ala aswaja, Nahdlatul Ulama menempatkan semua manusia pada kedudukan yang sama di hadapan Allah SWT., sebagaimana firman-Nya:

"Hai manusia! Sungguh Kami menciptakan kalian dari seorang lakilaki dan seorang perempuan dan Kami jadikan kalian berbangsabangsa dan bersuku-suku, supaya kalian saling mengenal. Sungguh orang yang paling mulia di antara kalian di sisi Allah ialah orang yang paliung bertaqwa. Sungguh Allah Maha Mengetahui dan Maha Mengenal,"29

${ }^{28}$ KH. Achmad Siddiq, Khittah Nahdliyyah, 66-68.

${ }^{29}$ QS. Al-Hujurat: 13 
Saling mengenal (li ta'arofuu) artinya saling mengerti, saling menghormati dan saling membantu. Manusia di hadapan Allah adalah makhluk yang terhormat, sebagaimana firman-Nya:

"Sungguh, Kami muliakan anak-anak Adam, Kami angkut mereka (Kami beri kemampuan dalam angkut mengangkut) di daratan dan di lautan. Kami beri mereka rizki dari yang baik-baik dan Kami lebihkan mereka dengan kelebihan yang sempurna atas kebanyakan makhluk yang telah Kami ciptakan. "30

Berangkat dari dua sikap: li ta'arofuu (saling mengerti) dan karromna (saling menghormati) itu, Islam mengatur hubungan antar sesama manusia yang berkembang dengan saling menolong, saling membantu, saling mengasihi, dan seterusnya. Manusia yang hidup bersama dan saling berhubungan itu bermacam sifat hubungannya. Ada yang dihubungkan dengan sifat famili/kekerabatan, ada yang dihubungkan dengan tempat tinggal/ketetanggaan, dengan pekerjaan, tempat pendidikan, ada yang dihubungkan dengan kesukuan, kebangsaan dan ada yang dihubungkan dengan kemanusiaan. ${ }^{31}$ Hal-hal inilah yang diperjuangkan oleh pendidikan aswaja NU secara hakiki.

Hakikat pendidikan NU ala aswaja adalah memanusiakan manusia (humanisasi) dengan cara mentransmisikan ajaran-ajaran yang Islami, membina IQ (Intellegence Quotion), EQ (Emotional Quotion), dan SQ (Spiritual Quotion), juga mengarahkan minat dan bakat peserta didik. NU dengan ajaran aswaja melihat ada tiga jenis hubungan antar manusia yang sangat besar pengaruhnya terhadap kehidupan, yaitu: a). Hubungan kesamaan agama (ukhuwah Islamiyah), b). Hubungan kesamaan bangsa (ukhuwah wathaniyah), dan c). Hubungan globalsesama manusia (ukhuwah basyariyah).

Pendidikan aswaja mengatur hubungan antar manusia dalam tiga macam ikatan di atas, yang menuju kepada persaudaraan/ kerukunan berdasar saling mengerti dan menghornati. Persaudaraan/kerukunan yang diajarkan oleh Islam ini disebut dengan persaudaraan (ukhuwah) yang diajarkan oleh Islam. Dengan mengemukakan tri ukhuwah di atas,

${ }^{30}$ QS. Al-Isra: 70

${ }^{31}$ Abdul Muchith Muzadi, Mengenal Nahdlatul Ulama, 32

Jurnal Pendidikan Agama Islam

Volume 01 Nomor 01 Mei 2013

Hal $176-179$ 
Nahdlatul Ulama menegaskan bahwa Islam mengajarkan persaudaraan dengan segala macam kelompok manusia; antara lain kelompok seagama, sebangsa, dan sesama manusia. ${ }^{32}$

Aswaja NU menjadi ideologisasi, bukan sebatas kajian, sebab banyak orang yang pandai al-Quran misalnya, tetapi hanya sebatas kajian, maka sering orang itu tidak berperilaku Qurani. Dalam hal cerita misalnya, pemilihan materi Aswaja adalah tentang peristiwa yang mencerminkan perilaku yang toleran, misal Ali yang dermawan, sabar, dan bukan Ali yang menjadi pahlawan gagah di perang Khaibar dan membunuh banyak musuh. Hal ini tentu berbeda dengan materi Aswaja yang diberikan oleh orang non-NU, yang sering memilih ayat-ayat dan cerita-cerita yang ekstrim dan tidak toleran.

Oleh karena itu, masyarakat NU itu tidak kereng dan ekstrim. Kalau NU kereng maka bahaya bagi negara ini, karena NU mayoritas; makanya NU memilih ajaran Islam yang toleran. Dengan demikian orang-orang NU itu sadar akan pentingnya pendidikan berwawasan plural yang ada di lingkungannya dalam rangka menjaga nilai pliralitas bangsa ini. NU berusaha agar Islam di Indonesia itu seperti yang pernah disebarkan para wali, yakni menjadi nilai-nilai budaya yang dimiliki bangsa yang kemudian disisipi dengan nilai Islam.

Dalam proses penyampaian ilmu, pendidikan aswaja NU berpijak pada landasan musyawarah (diskusi). Prinsip musyawarah merupakan unsur esensial dalam NU. Lembaga syuriah pun terikat dengan prinsip musyawarah sehingga dominasi kepemimpinannya baru mengikat seluruh organisasi (jam'iyah) atas keputusan musyawarah. Penndapat seorang perorang dari lembaga syuriyah belum merupakan kekuatan yang mengikat. Musyawarah dalam NU dilakukan dengan maksud mencari kebenaran, bukan mencari kekuatan berdasar wibawa atau jumlah suara terbanyak saja. Kalau sesuatu sudah diputuskan berdasarkan musyawarah dan sesuai dengan norma-norma agama, maka seluruh tubuh organisasi terikat dengan keputusan itu. ${ }^{33}$ Dalam al-Quran dinyatakan; "Ajaklah

${ }^{32}$ Abdul Muchith Muzadi, Mengenal Nahdlatul Ulama, 32-33.

${ }^{33}$ KH. Achmad Siddiq, Khittah Nahdliyyah, 70. 
olehmu (Muhammad) mereka bermusyawarah. Kalau sudah engkau mantap, maka bertawakkallah kepada allah. ",34

Proses transfer ilmu dan nilai dalam pendidikan adalah suatu proses yang tidak bebas nilai tetapi bebas dinilai. Oleh karena itu dalam tradisi keilmuan NU terdapat istilah qaul qadim (ajaran lama) dan qaul jadid (ajaran baru). ${ }^{35}$ Lebih dari itu, doktrin populer NU dalam pengembangan keilmuannya adalah "Menjaga tradisi lama yang baik dan mengambil tradisi baru yang lebih baik". Hal ini menunjukkan bahwa tradisi keilmuan dalam ajaran aswaja NU itu bersifat dinamis dan tidak stagnan, dengan berlandaskan pronsip musyawarah.

\section{G. Kesimpulan}

Pendidikan aswaja NU bersifat plural, multikultural, toleran, tasamuh, tawazun, dan sejenisnya. Lanaa a'maalana walakum a'malukum (bagi kami perbuatan kami, bagui kamu perbuatan kamu); lakum diinukum waliya diin (bagimu agamamu, bagiku agamaku). Jadi pendidikan NU itu berwawasan pluralistik.

Pendidikan aswaja NU mengatur hubungan antar manusia dalam tiga macam ikatan di atas, yang menuju kepada persaudaraan/ kerukunan berdasar saling mengerti dan menghornati. Persaudaraan/kerukunan yang diajarkan oleh Islam ini disebut dengan persaudaraan (ukhuwah) yang diajarkan oleh Islam. Dengan mengemukakan tri ukhuwah di atas, Nahdlatul Ulama menegaskan bahwa Islam mengajarkan persaudaraan dengan segala macam kelompok manusia; antara lain kelompok seagama, sebangsa, dan sesama manusia.

\footnotetext{
${ }^{34}$ QS. Ali Imran: 159.

${ }^{35}$ Imam Chuseno, Gerakan Dakwah dan Pendidikan Jam'iyah NU di Pulau Jawa (Periode Muktamar NU ke 27 Situbondo 1984 - Muktamar 28 Krapyak Yogyakarta 1990, Disertasi (Yogyakarta: UIN SuKa, 2003). 


\section{DAFTAR PUSTAKA}

Al-Quran AL-Karim

Al-Hadits Al-Nabawy

Abdul Muchith Muzadi, Mengenal Nahdlatul Ulama, Cet. IV (Jember: Masjid Sunan Kalijaga, 2006).

Faisal Ismail, NU, Gusdurisme, dan Politik Kiai (Yogyakarta: Tiara Wacana, 1999)

Imam Chuseno, Gerakan Dakwah dan Pendidikan Jam'iyah NU di Pulau Jawa (Periode Muktamar NU ke 27 Situbondo 1984 - Muktamar 28 Krapyak Yogyakarta 1990, Disertasi (Yogyakarta: UIN SuKa, 2003).

KH. Achmad Siddiq, Khittah Nahdliyyah, cet. III (Surabaya: KhalistaLTNU, 2005).

Lembaga Pendidikan Ma'arif Nahdlatul Ulama, Hasil Keputusan-Keputusan Musyawarah Kerja Nasional LPM-NU ke III: Sistem Pendidikan di Lingkungan Nahdlatul Ulama sebagai Sub Sistem Pendidikan Nasional; Lampiran 8 Landasan Dasar Kebijaksanaan Pendidikan di Lingkungan Nahdlatul Ulama (Jakarta, tt.).

Laode Ida, Anatomi Konflik: NU Elit Islam dan Negara (Jakarta: Sinar Harapan, 1996)

Muhammad Abdulhadi al-Mishri, Manhaj Aqidah Ahlussunnah wal jama'ah menurut Pemahaman Ulama Salaf, terj. As'ad Yasin, Abu Fahmi Ibnu Maryam (Jakarta: Insan Press, 1992).

PB NU, Khittah Nahdlatul Ulama (Jakarta: Lajnah Ta'lif an-Nasyr, 1985).

Said Aqil Siradj, Ahlus Sunnah Wal-Jama'ah dalam Lintas Sejarah (Yogyakarta, LKPSM, 1998) 